\title{
ROZKŁAD SIŁ WEWNĘTRZNYCH W BELKACH ŻELBETOWYCH BEZ ZBROJENIA NA ŚCINANIE
}

\begin{abstract}
W artykule przedstawiono wyniki badań na ścinanie belek żelbetowych bez zbrojenia poprzecznego. Parametrem zmiennym była smukłość ścinania wynosząca odpowiednio 1,$0 ; 1,5 ; 2,0$ oraz 3,0 . Badania pokazały, że pod wpływem ścinania następuje zmiana rozkładu sił wewnętrznych $\mathrm{w}$ strefie przypodporowej. Prowadzi to do zmniejszenia naprężeń ściskających w „ściskanej” części belki już we wstępnej w fazie formowania się krytycznej rysy ukośnej, która przecina oś zbrojenia w odległości d od podpory i jest to przekrój miarodajny do wymiarowania na ścinanie.
\end{abstract}

Słowa kluczowe: ścinanie, belki żelbetowe, smukłość ścinania, elementy bez zbrojenie poprzecznego

\section{Wstęp}

Zagadnienie nośności na ścinanie w elementach żelbetowych jest analizowane od ponad stu lat. Liczne badania wykazały, że w przypadku elementów bez zbrojenia poprzecznego, o nośności na ścinanie decydują nie tylko parametry związane z właściwościami fizycznymi zastosowanych materiałów. Istotny wpływ ma zarówno geometria samego elementu, jak i sposób, i schemat obciążenia. W tej ostatniej grupie tzw. smukłość ścinania jest jednym z ważniejszych czynników decydujących o nośności elementu $[1,2]$.

\section{Program badań}

Program badań własnych wzorowano w zakresie podstawowych założeń na badaniach przeprowadzonych w Stuttgarcie przez Leonhardta i Walthera [3]. Badania tych autorów koncentrowały się w głównej mierze na zagadnieniu nośności elementów, z tego względu nie prowadzono żadnych innych pomiarów, zarówno odkształceń betonu, jak również naprężeń w zbrojeniu głównym.

Jako element badawczy wybrano jednoprzęsłową belkę żelbetową o przekroju prostokątnym $0,15 \times 0,30 \mathrm{~m}$ i wysokości użytecznej $\mathrm{d}=0,27 \mathrm{~m}$. Zbrojenie dolne stanowiły dwa pręty ze stali żebrowanej o średnicy $22 \mathrm{~mm}-\rho_{\mathrm{L}}=1,90 \%$

\footnotetext{
${ }^{1}$ Przemysław Bodzak, Politechnika Łódzka Katedra Budownictwa Betonowego, Al. Politechniki 6, 90-924 Łódź, tel. 42-631-35-75, e-mail: pbodzak@p.lodz.pl
} 
$\left(\right.$ AIII, $\left.\mathrm{f}_{\mathrm{yk}}=410 \mathrm{MPa}\right)$. Belkę obciążano dwiema siłami skupionymi w rozstawie $0,27 \mathrm{~m}$. W celu uzyskania zróżnicowanych smukłości ścinania tzn. 1,0;1,5;2,0; 3,0, długość odcinka przypodporowego ,a” wynosiła odpowiednio 0,27; 0,405; 0,$54 ; 0,81 \mathrm{~m}$ - rys. 1 . Ze względu na brak zbrojenia poprzecznego nie zastosowano zbrojenia górnego w tych elementach. Przygotowując program badań założono, że elementy serii I zostaną wykonane $\mathrm{z}$ betonu o wytrzymałości $\mathrm{f}_{\mathrm{c} \text {,cube }}=35 \mathrm{MPa}$, natomiast serii II z betonu o wytrzymałości nie większej niż 25MPa.

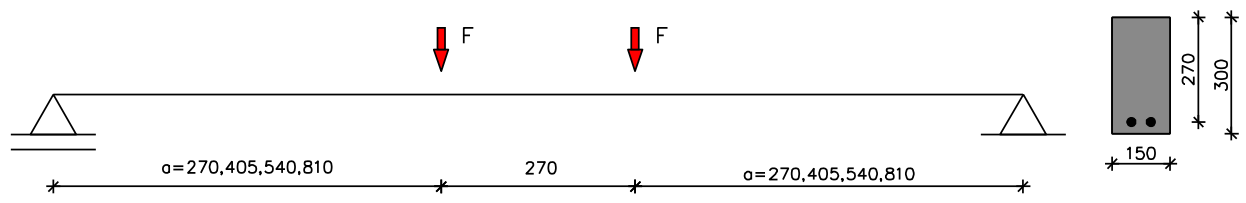

Rys. 1. Schemat stanowiska badawczego dla normowych badań na ścinanie

Fig. 1. Test setup to determine the shear strength according to [1]

W trakcie badań mierzono odkształcenia betonu zarówno przy dolnej, jak i górnej krawędzi elementu, za pomocą nasadowego ekstensometru mechanicznego o bazie $100 \mathrm{~mm}$. Układ baz pomiarowych pokazano na rys. 2 .
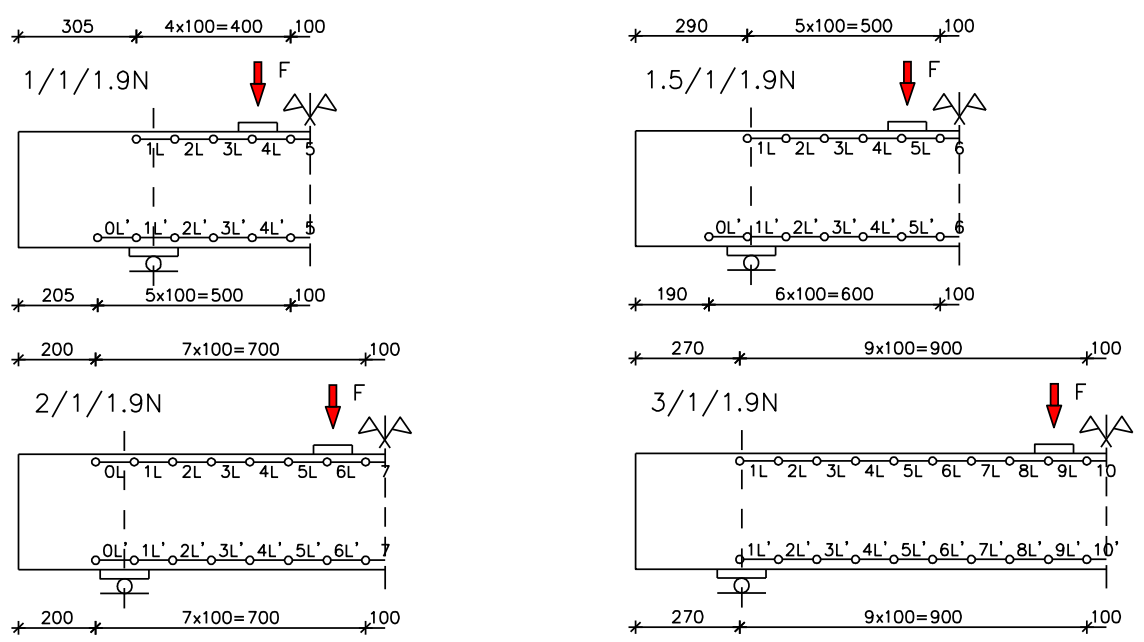

Rys. 2. Schemat rozmieszczenia punktów pomiarowych

Fig. 2. Layout of measuring points

\section{Wyniki badań}

Badania elementów zostały wykonane po 28 dniach od daty betonowania. Zestawienie obciążeń rysujących (zarysowanie ukośne) oraz sił niszczących, a także wytrzymałość betonu przedstawiono w tablicy 1 . 
Powstanie rys ukośnych w strefie przypodporowej nie zawsze było jednoznaczne ze zniszczeniem elementu, mimo braku zbrojenia poprzecznego. Jedynie przy smukłości ścinania a/d $=3,0$ powstanie rysy ukośnej przy jednej z podpór prowadziło do wyczerpania nośności. Dla elementów o mniejszych smukłościach $(1,0 ; 1,5$ oraz 2,0$)$ ukośne zarysowanie przy jednej z podpór nie oznaczało jeszcze zniszczenia. Przy kolejnych poziomach obciążenia rysa ukośna tworzyła się przy przeciwległej podporze i nawet takie zarysowanie nie było jednoznaczne $\mathrm{z}$ wyczerpaniem nośności, a zniszczenie następowało przy obciążeniu większym od obciążenia rysującego o $35 \%$ do $280 \%$. Widok elementów po badaniu wraz z układem rys pokazano na rys. 3 .

Tablica 1. Charakterystyka i wyniki badań elementów

Table 1. Geometric data and cracking loads and shear capacity

\begin{tabular}{|c|c|c|c|c|c|c|c|c|c|}
\hline Seria & Oznaczenie $^{1)}$ & $\begin{array}{l}a \\
\mathrm{~m}\end{array}$ & $a / d$ & $\begin{array}{c}\boldsymbol{F}_{\boldsymbol{c r}, \boldsymbol{L}} \\
\mathrm{kN}\end{array}$ & $\begin{array}{c}\boldsymbol{F}_{\boldsymbol{c} \boldsymbol{r}, \boldsymbol{R}} \\
\mathrm{kN}\end{array}$ & $\begin{array}{c}f_{c, \text { cube }} \\
\mathrm{MPa}\end{array}$ & $\begin{array}{c}\boldsymbol{F}_{u^{\text {test }}} \\
\mathrm{kN}\end{array}$ & $\begin{array}{c}\tau_{t}^{t e s t} / f_{c t m} \\
\mathrm{MPa}\end{array}$ & $\begin{array}{c}\boldsymbol{M}_{u}{ }^{\text {test }} / M_{\text {cal }} \\
\%\end{array}$ \\
\hline \multirow{4}{*}{ I } & $1 / 1 / 1.9$ & 0,27 & 1,0 & 150 & 170 & 37,0 & 540 & 2,41 & 104 \\
\hline & $1.5 / 1 / 1.9$ & 0,42 & 1,5 & 130 & 130 & 36,0 & 278 & 1,26 & 80 \\
\hline & $2 / 1 / 1.9$ & 0,54 & 2,0 & 120 & 120 & 37,0 & 168 & 0,75 & 65 \\
\hline & $3 / 1 / 1.9$ & 0,81 & 3,0 & - & 118 & 37,0 & 118 & 0,52 & 67 \\
\hline \multirow{3}{*}{ II } & $1.5 / 1 / 1.9 \mathrm{~L}$ & 0,42 & 1,5 & 140 & 120 & 34,0 & 284 & 1,34 & 82 \\
\hline & $2 / 1 / 1.9 \mathrm{~L}$ & 0,54 & 2,0 & 120 & 130 & 31,0 & 155 & 0,75 & 58 \\
\hline & $3 / 1 / 1.9 \mathrm{~L}$ & 0,81 & 3,0 & 115 & - & 31,0 & 115 & 0,55 & 64 \\
\hline
\end{tabular}

Pomiary odkształceń wykonywane były po każdym przyroście obciążenia. Na rys. 4. oraz 5. przedstawione zostały wykresy, ilustrujące odkształcenia betonu przy wybranych poziomach obciążenia jedynie wzdłuż górnej tzw. „ściskanej" krawędzi elementu. Zgodnie z oczekiwaniami w początkowej fazie obciążenia odkształcenia betonu są ujemne (ściskanie) i proporcjonalne do wartości momentu zginającego, tj. w tym przypadku od odległości od podpory.

Począwszy od obciążenia wynoszącego, w zależności od smukłości ścinania około $100-120 \mathrm{kN}$, na odcinku pomiędzy podporą a obciążeniem skupionym zasada ta zostaje zaburzona. Wykres naprężeń nie tworzy linii prostej pomiędzy podporą a punktem przyłożenia obciążenia, jak należałoby tego oczekiwać ze względu na liniową zmienność momentu na tym fragmencie belki. Przy kolejnych poziomach obciążenia, mimo jego wzrostu, naprężenia w strefie ściskanej nie przyrastają już proporcjonalnie. W następstwie tego przy „ściskanej” krawędzi belki odkształcenia maleją, od pewnego poziomu obciążenia występują nawet odkształcenia dodatnie (rozciąganie). Przy smukłości ścinania 1,0;1,5 oraz 2,0 odkształcenia dodatnie pojawiają się przy górnej ściskanej krawędzi belki przy obu podporach. Wartości tych odkształceń dodatnich są znaczne, i w zależności od elementu, przekraczają nawet $2 \%$ o. Widoczne jest to w układzie rys (por. rys. 3.), które występują również przy górnej krawędzi elementu. 

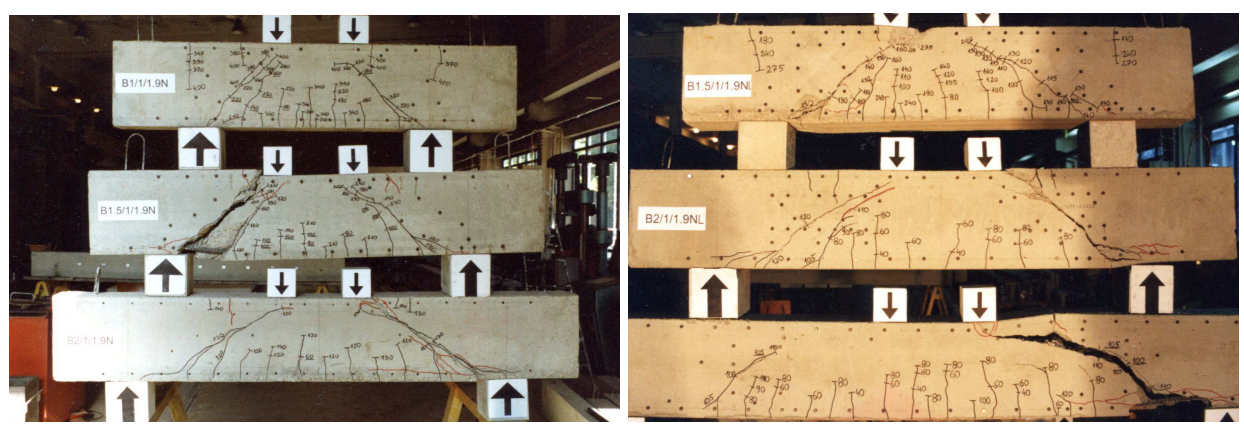

Rys. 3. Widok elementów serii I oraz II po zniszczeniu

Fig. 3. Tests elements of series I and II after failure
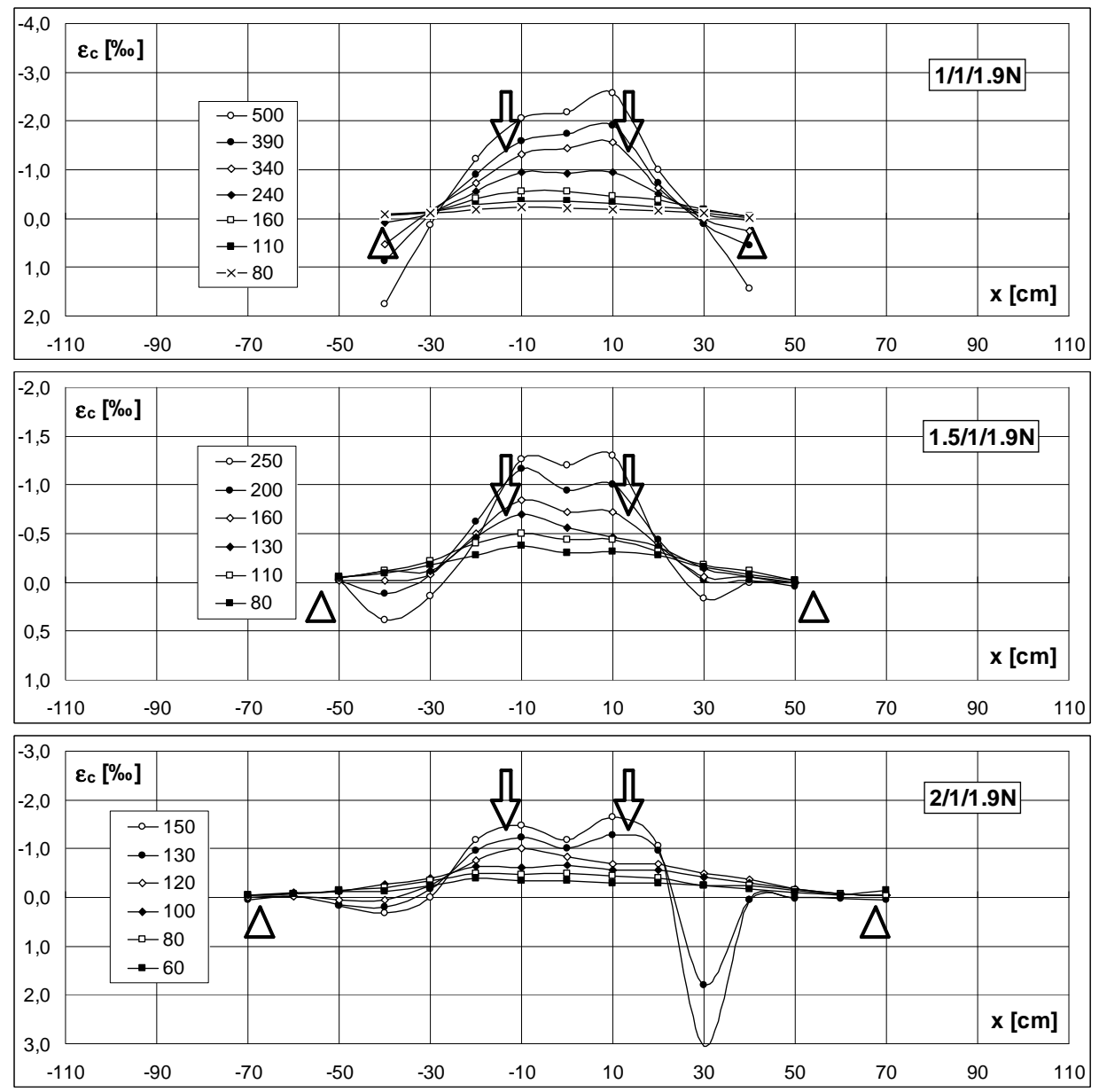

Rys. 4. Naprężenia ściskające wzdłuż górnej krawędzi belki - seria I

Fig. 4. Compression stress along upper edge of the beam - I series 

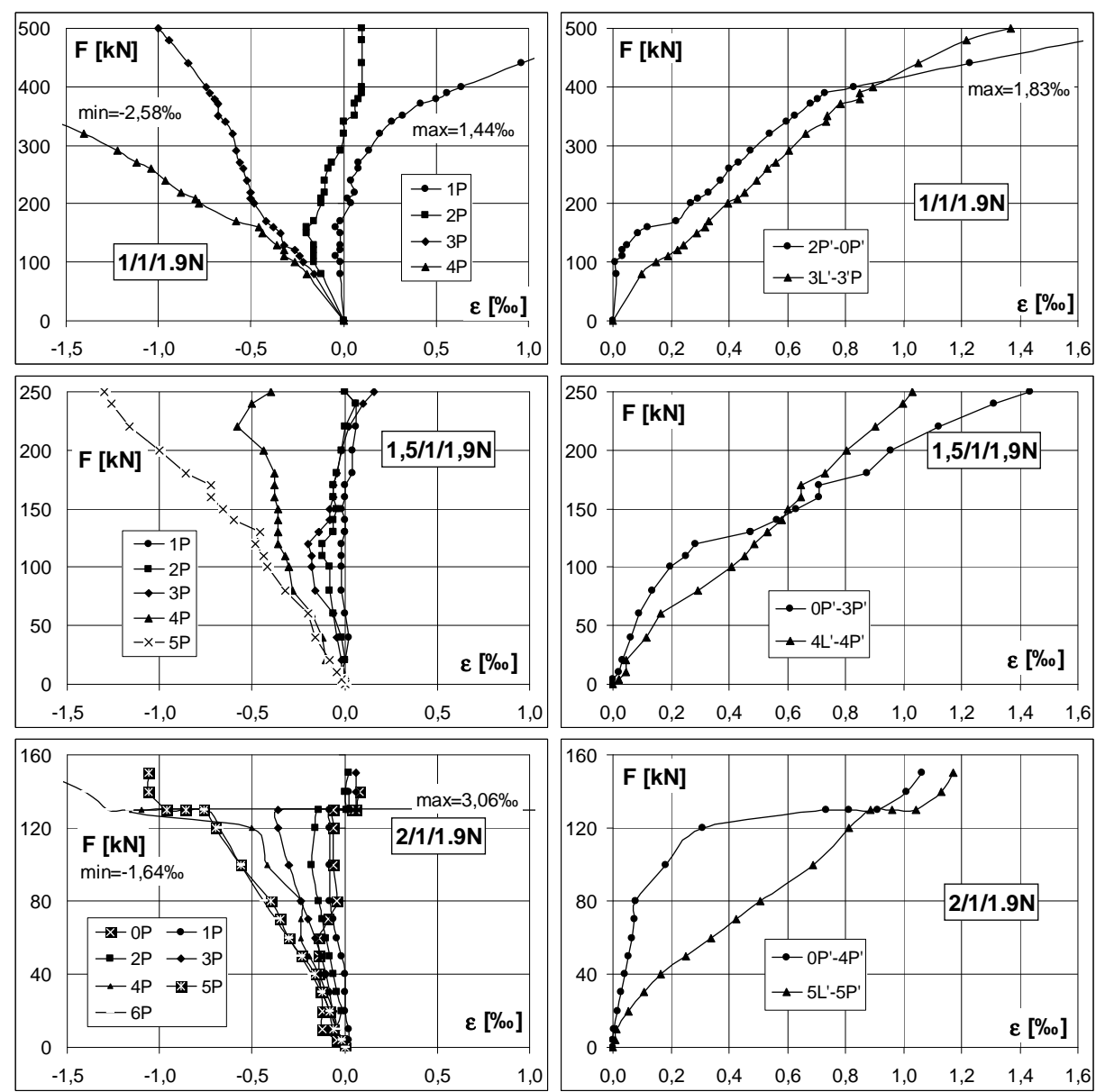

a)

b)

Rys. 5. Seria I - naprężenia: a) ściskające przy górnej krawędzi belki b) średnie rozciągające

Fig. 5. I series - compression: a) stress at the upper edge of the beam, b) average tension

Jedynie elementy o smukłości ścinania 3,0 nie uległy w trakcie badania zarysowaniu przy górnej krawędzi, gdyż powstanie rys ukośnych prowadziło jednocześnie do wyczerpania nośności. Widoczne na rysunku 3. rysy przy górnej krawędzi elementu powstały w chwili zniszczenia równocześnie z rysami ukośnymi.

Na rysunku 5. przedstawiono zależności pomiędzy obciążeniem a odkształceniami pomierzonymi wzdłuż górnej i dolnej krawędzi belki po jednej stronie elementu - układ baz por. 2. Odkształcenia przy górnej krawędzi przedstawiono dla każdej bazy niezależnie (rys. 5a), natomiast odkształcenia przy dolnej krawędzi (rys. 5b) są to wartości średnie zarówno w części środkowej belki (5 baz), jak również na odcinku przypodporowym. Analizując wykresy odkształceń na poszczególnych bazach wzdłuż górnej krawędzi elementu można zauważyć, że przyrost obciążenia powoduje proporcjonalny wzrost odkształceń wzdłuż 
wszystkich baz jedynie do obciążenia wynoszącego $100 \mathrm{kN}$ tj. mniejszego o około $15 \div 30 \mathrm{kN}$ od obciążenia powodującego powstanie rys ukośnych. Taka zależność dotyczy wszystkich belek, również o smukłości ścinania a/d $=3,0$. Po osiągnięciu tego „granicznego” poziomu obciążenia, odkształcenia wzdłuż niektórych baz nie zwiększają się mimo wzrostu obciążenia elementu i po kolejnym przyroście początkowo pozostają na stałym poziomie, następnie stopniowo zmniejszają się, a w niektórych przypadkach, bezpośrednio przed zarysowaniem, radykalnie maleją. Powstanie rys ukośnych prowadzi do raptownego przegrupowania sił wewnętrznych i nagłej zmiany znaku odkształceń co oznacza występowanie rozciągania zamiast ściskania. Obrazem zewnętrznym takiego nowego układu sił w belce są rysy występujące przy górnej krawędzi elementu.

Wielkości odkształceń wzdłuż dolnej krawędzi belki przeanalizowano jako wartości średnie, ponieważ rysy występujące w tej strefie intensywnie zaburzają obraz odkształceń i przez to naprężeń. Ze względu na znaczne skoki wartości na poszczególnych bazach, wynikające właśnie z powstałych rys, obraz byłby trudny do jednoznacznej analizy. W początkowej fazie badania przyrosty odkształceń są proporcjonalne do poziomu obciążenia, zarówno w części środkowej elementu, jak i na odcinku przypodporowym. Widoczna jest oczywiście różnica w wartościach odkształceń wynikająca $\mathrm{z}$ innych wartości średnich momentów zginających na obu fragmentach belki. Taka zależność jest prawdziwa jedynie do obciążenia około $100 \mathrm{kN}$. Począwszy od tej wartości siły przyrost odkształceń w strefie przypodporowej jest znacznie większy niż w części środkowej belki. Prowadzi to do sytuacji, w której odkształcenia w strefie przypodporowej są większe niż w części środkowej belki, co sugeruje, że element przekształca się stopniowo z ustroju belkowego w ściągowo-rozporowy.

Jak wspomniano wcześniej zjawisko stabilizacji odkształceń w strefie ściskanej mimo wzrostu obciążenia, a następnie ich stopniowego zmniejszania się, widoczne jest również $\mathrm{w}$ elementach o smukłości ścinania $\mathrm{a} / \mathrm{d}=3,0$. Właśnie wyniki badań tych elementów zasługują na szczególną uwagę. Na rysunku 7. przedstawiono obraz zarysowania oraz wykresy odkształceń na bazach $1 \div 6$ wzdłuż krawędzi ściskanej elementu 3/1/1.9L dla obu stref przypodporowych. Proporcjonalny przyrost odkształceń na poszczególnych bazach widoczny jest do obciążenia wynoszącego około $90 \mathrm{kN}$ przy podporze prawej oraz $80 \div 90 \mathrm{kN}$ przy podporze lewej. Przy kolejnym przyroście obciążenia zasada to zostaje wyraźnie zaburzona - por. baza $2 \mathrm{P}$ oraz $3 \mathrm{P}$. Począwszy od obciążenia wynoszącego $100 \mathrm{kN}$ zarówno po prawej jak i lewej stronie elementu tworzą się kolejne rysy „od zginania”, jednak nie są to rysy o kierunku prostopadłym do zbrojenia głównego. Ich pochylenie wskazuje na znaczne odchylenie kierunku naprężeń głównych i wpływ ścinania na kształtowanie się układu tych rys. Zaburza to swobodnie przekazywanie sił ściskających w ramach schematu ściągowegorozporowego, zarówno ze względu na położenie rys, jak ich wnikanie na znaczną wysokość elementu. Konsekwencją tych zmian przy smukłości ścinania równej 3 jest stopniowa przebudowa klasycznego schematu ściągowo-rozporowego na schemat płaskiego łuku ze ściągiem i sztywnymi strefami przypodporowymi. 


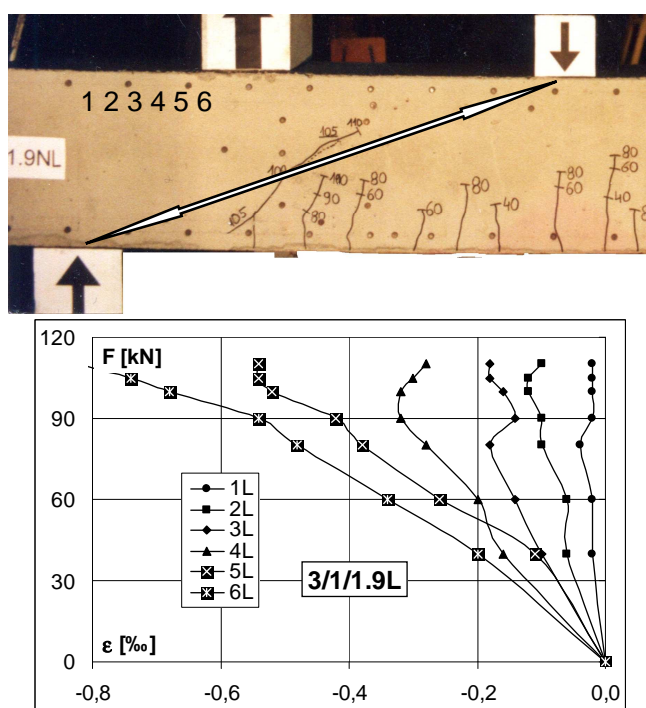

a)
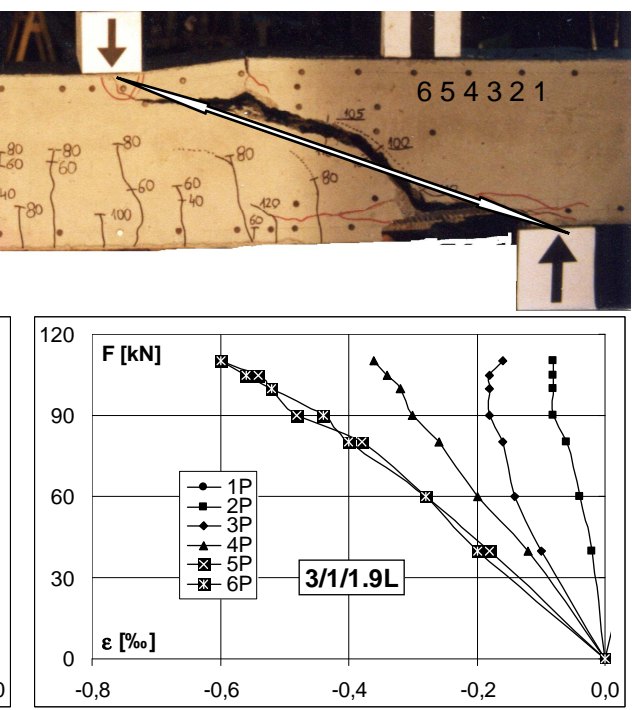

b)

Rys. 6. Naprężenia ściskające przy górnej krawędzi belki 3/1/1.9L a) lewa, b) prawa część

Fig. 6. Compression stress at the upper edge of the beam 3/1/1.9L a) left, b) right part

Stabilność takiego układu uzależniona jest od miejsca przyłożenia obciążenia zewnętrznego - rys. 7. Dla smukłości ścinania a/d=1 belka mimo powstania rys jest $\mathrm{w}$ równowadze dzięki układowi ściągowo-rozporowemu i bezpośredniemu przekazywaniu obciążenia w kierunku podpory. Przy smukłości ścinania równej 2 (rys. 7a) obciążenie zewnętrzne znajduje się na granicy sztywnego bloku podporowego wydzielonego przez rysy ukośne, natomiast gdy smukłość ścinania jest większa od 2 obciążenie przyłożone jest na płaskiej części mało wyniosłego łuku - rys. 7 b. Powstanie rysy przecinającej krzyżulec ściskany prowadzi do stopniowej destabilizacji całego układu i zniszczenia elementu. Punkt obrotu „A” dla wydzielonych sztywnych elementów znajduje się na końcu rysy najbliższej podporze.

Należy przyjąć, że krytyczne rysy od ścinania przecinają oś zbrojenia w odległości $1 \mathrm{~d}$ od podpory, a nie $0,5 \mathrm{~d}$ jak wynika z [2,3] i dla takiego przekroju należy prowadzić analizy obliczeniowe. Lokalizacja krytycznej rysy w odległo-

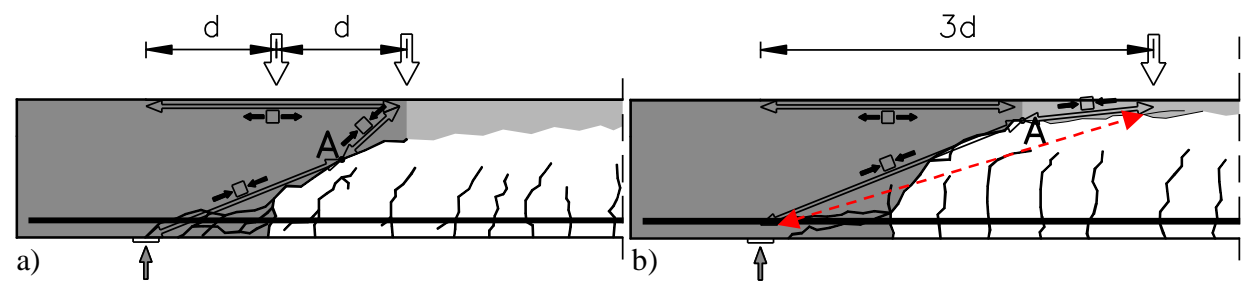

Rys. 7. Schemat belki bez zbrojenia na ścinanie przed zmieszczeniem

Fig. 7. RC beams without shear reinforcement before damage 
ści d i wydzielenie sztywnego bloku podporowego o długości 2 d pokrywa się ze wcześniejszymi obserwacjami dotyczącymi belek o różnych smukłościach i obciążonych w sposób jednorodny [4].

\title{
4. Wnioski
}

W elementach żelbetowych bez zbrojenia poprzecznego przy obciążeniach mniejszych o 10 - 15\% od obciążeń powodujących powstanie rys ukośnych, naprężenia w strefie ściskanej belek nie przyrastają już proporcjonalnie do wzrostu obciążenia, lecz stabilizują się lub stopniowo zmniejszają się. Jest to początkowa faza przebudowy rozkładu sił wewnętrznych poprzedzająca powstanie rysy ukośnej. W fazie bezpośrednio poprzedzającej zarysowanie ukośne następuje nawet zmiana znaku i przy krawędzi ,ściskanej” występuje rozciąganie, co manifestuje się zarysowaniem tej części belki. Krytyczna rysa ukośna wydziela sztywny blok przypodporowy o długości $2 \mathrm{~d}$ i przecina oś zbrojenia w odległości $1 \mathrm{~d}$ od podpory, a nie $0,5 \mathrm{~d}$. Właśnie dla przekroju oddalonego od podpory o „d" należy prowadzić analizy obliczeniowe stosując zalecenia Model Code 2010.

\section{Literatura}

[1] Muttoni A., Fernández Ruiz M., Shear strength of members without transverse reinforcement as function of critical shear crack width ACI Structural Journal, V. 105, No 2, Farmington Hills, USA, 2008, pp. 163-172.

[2] fib Model Code for Concrete Structures 2010 October 2013, Ernst \& Sohn.

[3] Leonhardt F., Walther R., Schubversuche an einfeldingen Stahlbetonbalken mit und ohne Schubbewehrung. Heft 151. Deutscher Ausschluss fur Stahlbeton. Berlin 1962.

[4] Bodzak P., Efekt tarczowy w żelbetowych elementach prętowych bez zbrojenia poprzecznego. „Inżynieria i Budownictwo”, nr 11/2006, s. 226-229.

\section{REDISTRIBUTION OF INTERNAL FORCES IN RC BEAM WITHOUT SHEAR REINFORCEMENT}

\begin{abstract}
S u m m a r y
The article presents comparison of experimental test results carried out on RC beams with different shear ratio and without shear reinforcement. According to this tests results in beams without transverse reinforcement the influence of shear is seen in the form of stress redistribution in the compression zone already before the diagonal cracking. This demonstrates in the form of stress reduction in the compression zone of the beam and in the subsequent load steps in the form of stretching and consequently cracking of "compression" part of the beam.
\end{abstract}

Keywords: shear, $\mathrm{RC}$ beams, shear ratio, $\mathrm{RC}$ beams without shear reinforcement 